\title{
New species in the Hungarian avifauna in 2015
}

\author{
Tibor HADARICS
}

Received: August 4, 2016 - Accepted: November 30, 2016

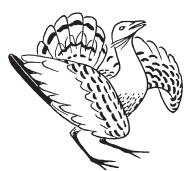

Tibor Hadarics 2016. New species in the Hungarian avifauna in 2015. - Ornis Hungarica 24(2): 78-83.

The bird was seen and photographed in Népliget, Budapest on the $31^{\text {st }}$ of December. With this observation, the number of bird species detected in Hungary has risen to 412.

Keywords: official bird checklist, Hungarian Checklist and Rarities Committee, Naumann's Thrush, Turdus naumanni

Összefoglalás 2015-ben egy faunára új madárfaj bukkant fel Magyarországon: a Naumann-rigó. A madarat 2015. december 31-én figyelték meg és fényképezték le a budapesti Népligetben. E faj előkerülésével a Magyarországon valaha bizonyítottan előfordult madárfajok száma 412-re emelkedett.

Kulcsszavak: Magyarország madarainak névjegyzéke, MME Nomenclator Bizottság, Naumann-rigó, Turdus naumanni

Tibor Hadarics, 9400 Sopron, Wälder József utca 4.D/2., Hungary, e-mail: sitke@upcmail.hu

In 2015, the Naumann's Thrush was accepted by the Hungarian Checklist and Rarities Committee as new to the Hungarian fauna. By this, number of bird species observed in Hungary to date, has risen to 412 .

Turdus naumanni Temminck, 1820 - Naumann's Thrush

$31^{\text {st }}$ December 2015, Budapest, Népliget, 1 ad. exemplar (D. Laposa and others)

The Naumann's Thrush (T. naumanni) was formerly considered as conspecific with the Dusky Thrush (T. eunomus). The taxonomic separation of the two species is based on their distinctly different plumages. The Dusky Thrush breeds in the northern parts of Central and Eastern Siberia, while the breeding area of Naumann's Thrush is located south of the Dusky Thrush's range with wide overlapping regions in the western (naumanni) and southwestern (eunomus) parts of their ranges (Clement 1999). Naumann's Thrush breeds in the southern parts of Central and Eastern Siberia, from the central Yenisey region east to the middle and upper Lena Basin. The southern boundary of the distribution is uncertain, perhaps discontinuous east of Lake Baikal, but embracing Angara basin in the west along with the southern part of Lake Baikal. Small numbers also breed north of the main range, near the Lena and Olenek deltas (Clement \& Hathway 2000, del Hoyo et al. 2005). It winters mainly in China, ranging from extreme Southeast Russia and Korean Peninsula south to Eastern China (Yangtze basin) but some birds reach also Japanese islands and Taiwan (del Hoyo et al. 2005). 
Preferred habitats of Naumann's Thrush are fringes of lowland tundra in thinning taiga and wooded steppe, dense riverine forests of willow and poplar, scrubby lowland areas with birch and alder. Less often it occurs in sparse larch or mixed larch and pine forest extending into open country or even in gardens (del Hoyo et al. 2005).

Of the two species, Dusky Thrush occurs in Europe more frequently than Neumann's Thrush for several possible reasons. On one hand, as the distribution area of the Dusky Thrush is larger, it also has a larger population size, and the western part of its distribution is nearer to Europe than that of the Naumann's Thrush with a smaller distribution range. On the other hand, as the Dusky Thrush has more northerly breeding area, it makes longer journeys during migration; long-distance migrants get to Europe more frequently due to reverse migration, compared to short-distance migrants (Gilroy \& Lees 2003, Lees \& Gilroy 2009, Pfeifer et al. 2007).

Based on historic data, it is often difficult to conclude whether the observed speciments represent occurrences of Naumann`s Thrush (sensu stricto) or Dusky Thrush, because were regarded to belong to one species; Turdus naumanni eunomus. Naumann`s Thrush has five records in Finland, Norway and Italy, seven in Poland, four in the Czech Republic, Germany and France, two in Great Britain and one in Belgium (Lewington et al. 1991, Slack 2009). Most of the data are from the late autumn and winter period (November-January), but there are occurrences also from October to spring. For example, there is an interesting observation from Bulgaria: six skeletal elements of Naumann's Thrush (sensu lato) were identified in food remains of an Eagle Owl in May 2003 in Southeastern Bulgaria (Milchev \& Boev 2014).

Of the countries neighbouring Hungary, it was only recorded in Austria, with two records (Glutz von Blotzheim \& Bauer 1988). Between 1853 and 1874 one male was acquired at the Vienna bird (food) market, most probably originating from the Wechsel mountains on the border between Styria and Lower Austria (this specimen is currently in the collection of Natural History Museum, Vienna). A second male was observed by R. Zach at Wolfsgraben (Lower Austria) on the $8^{\text {th }}$ of April in 1984.

There is only one record from the Carpathian Basin from the nineteenth century. In the 1820s, Pál Jány, the first official animal preparator of the Chamber of Naturalia of Hungarian National Museum purchased an adult male at a market in Pest for the museum collection. The bird was found at the game market together with Fieldfares (or other thrushes) caught with limesticks but the exact date and location of the capture remained unknown. However, it should not have been caught too far from Pest, because birds were not typically brought to the market from hundreds of kilometres (Magyar 2006, 2016). Johann Friedrich Naumann was in Hungary in the autumn of 1835 and made a visit at the bird collection of the Hungarian National Museum (Schnell 1835) where, among others, viewed the Naumann`s Thrush specimen and painted it for his upcoming book. Although he did not mention it in the report of his Hungarian trip (Naumann 1837), he reported on it in a later article (Naumann 1851). In the appendix of his book, J. A. Naumann's Naturgeschichte der Vögel Deutschlands (Naumann 1845-1854), he refers to it as a specimen from the Carpathians, providing a description along with his painting on plate 358. Afterwards, based on this data the species was regularly mentioned in Hungarian checklists. In the checklists of Kornhuber 
(1856), Madarász (1881) and Chernel (1888), it appeared without any further informations. Frivaldszky (1891) gave Hungary as the location of origin. The bird was displayed in an exhibition at the Second International Ornithological Congress, the catalogue of which also mentions Hungary as location of origin (Madarász 1891). In the two most important Hungarian ornithological books of the end of the nineteenth century (Chernel 1899, Madarász 1899-1903), as well as in István Chernel`s Brehm-translation (Chernel 1902), it appeared as having been collected in Hungary, without further specification. In the official checklists of the Ornithological Institute (Magyar Ornitológiai Központ 1898, Chernel 1918), the species appeared without date and location. In Schenk`s (1917) work, the location was given as the Carpathians (specimen unicum in montibus Carpathicis captum). Up to this date, the exact location of origin was of little importance, as whether it had been caught around Pest, in the Northern Uplands or the Upperlands, it was surely within the boundaries of the former Hungary. The Trianon Treaty (1920) changed the boundaries of Hungary, which also meant that the location of observations of several species has been moved outside the boundaries of the broken up country. Although the exact location of the Naumann's Thrush was unknown, of the possible locations, the Upperlands and the Carpathians became parts of Czechoslovakia (presently Slovakia). This made it questionable if the specimen purchased in the $1820 \mathrm{~s}$ at a market in Pest had been caught within the new boundaries of Hungary. Chernel (1922) in a passionate article regarded Naumann`s Thrush as a species from outside the new boundaries, as he listed it as a „loss” to the Hungarian species list. Lovassy (1927) mentioned it as a specimen originating from Hungary, with a note in the introduction of his book that he regards Hungary as the area of the Carpathian basin, i.e., not the slayed country after the Trianon Treaty. Schenk (1939), in his checklist, mentions the species as one from outside our boundaries, using different typography, thus, he regarded it as one from the Carpathians. By the 1950s, the species was not even mentioned in the bird volume of the 'Magyarország állatvilága' series (Farkas 1958), or in a later checklist (Farkas 1967). However, it re-appeared in the official checklist in 1960 (Keve 1960). It is unknown why Keve put it in the list, but it was surely a deliberate act, because his checklist had an appendix with those species that were in the previous fauna list but whose locations were outside the current boundaries of Hungary. However, Naumann`s Thrush is not in this list, but in the main one (Keve 1960). The proof specimen was destroyed during the 1956 Revolution (Keve 1960). The data and the species were then mentioned in two separate bird lists afterwards: Keve (1984) did not give location of origin (he only detailed the circumstances of the specimen getting into the collection), and Magyar (1998) gave the origin of location as the vicinity of Budapest. The species also appeared in the 'Magyarország madárvendégei' (Schmidt 1988) and in the 'Magyarország madarai' (Schmidt 1998) monographs, the latter suggesting that the bird had been collected in the mountains near Pest. As the location of the specimen collection is still uncharacterised, and as it cannot be concluded with certainty whether the collection was done within or outside of the current boundaries of Hungary, such as in present-day Slovakia, the Hungarian Rarities and Checklist Committee deleted both the data and the species from the official checklist of birds of Hungary (MME Nomenclator Bizottság 2010). As a consequence, the species only appears in the appendix of the latest checklist of the MME Nomenclator Bizottság (2008), which lists species with uncertain locations. 
The recent observation guarantees that the species can be now unquestionably listed in the official bird checklist, because its appearance was apparently proven in our country in 2015 .

\section{Acknowledgements}

I would like to express my gratitude to referees and Jenö Nagy and Zoltan Németh who made the English translation of the manuscript.

\section{References}

Chernel, I. 1888. A Magyarországban előforduló madarak névjegyzéke [Checklist of the birds occurring in Hungary]. - Vadászok Zsebnaptára 2: 57-79. (in Hungarian)

Chernel, I. 1899. Magyarország madarai különös tekintettel gazdasági jelentőségökre. Második könyv. Tüzetes rész. Magyarország madarainak leírása, elterjedése és életrajza [Birds of Hungary with special respect of their economic significance. Second book. Detailed part. Description, distribution and life history of the birds of Hungary]. - Magyar Ornithologiai Központ, Budapest, pp. 745-746. (in Hungarian)

Chernel, I. 1902. Az állatok világa. Brehm Alfréd „Tierleben” cimű nagy művének magyarba átültetett kiadása. Madarak. Első kötet. Varjúszerü madarak [Life of animals. Hungarian edition of the great work „Tierleben” of Alfred Brehm. Birds. First volume. Corvid birds]. - Légrády Testvérek, Budapest, pp. 86-87. (in Hungarian)

Chernel, I. (ed.) 1918. Nomenclator avium Regni Hungariae. A Magyar Birodalom madarainak névjegyzéke [Checklist of the birds of the Hungarian Empire]. - Magyar Királyi Ornithologiai Központ, Budapest, p. 58. (in Hungarian and German)

Chernel, I. 1922. A trianoni béke és Magyarország madárvilága [The Trianon Treatment and the avifauna of Hungary]. - Aquila 28: 41-47. (in Hungarian and German)

Clement, P. 1999. Kennzeichen und Taxonomie von Bechsteindrossel Turdus ruficollis und Naumanndrossel $T$. naumanni [Identification and taxonomy of Dark-throated Turdus ruficollis and Dusky Thrush T. naumanni]. - Limicola 13(5): 217-250. (in German with English Summary)

Clement, P. \& Hathway, R. 2000. Thrushes. - Christopher Helm - A \& C Black, London, pp. 381-386.

Farkas, T. 1958. Turdidae - Rigófélék [Turdidae - Thrushes]. - In: Székessy, V. (ed.) Aves - Madarak. - Akadémiai Kiadó, Budapest, pp. 1041-1059. (in Hungarian)

Farkas, T. 1967. Nomenclator der Vögel Ungarns [Checklist of the birds of Hungary]. - In: Farkas, T. (ed.) Ornithogeographie Ungarns. - Duncker \& Humblot, Berlin, pp. 166-196. (in German)

Frivaldszky, J. 1891. Aves Hungariae. Enumeratio systematica avium Hungariae cum notis brevibus biologicis, locis inventionis virorumque a quibus oriuntur [Birds of Hungary. Systematic specification of the birds of Hungary with short notes of their biology and finding places]. - Franklin Társulat, Budapest, p. 52. (in Latin)

Gilroy, J. J. \& Lees, A. C. 2003. Vagrancy theories: are autumn vagrants really reverse migrants? - British Birds 96(9): 427-438.

Glutz von Blotzheim, U. N. \& Bauer, K. M. (Hrsg.) 1988. Handbuch der Vögel Mitteleuropas. Band 11/II. Passeriformes (2. Teil). Turdidae [Handbook of the birds of Central Europe. Vol. 11/II. Passeriformes (Part 2). Turdidae]. - Aula-Verlag, Wiesbaden, pp. 948-967. (in German)

del Hoyo, J., Elliott, A. \& Christie, D. (eds.) 2005. Handbook of the birds of the World. Vol. 10. Cockoo-shrikes to thrushes. - Lynx Edicions, Barcelona, pp. 640-641.

Keve, A. 1960. Magyarország madarainak névjegyzéke. Nomenclator avium Hungariae [Checklist of the birds of Hungary]. - Madártani Intézet, Budapest, p. 64. (in Hungarian and German)

Keve, A. 1984. Magyarország madarainak névjegyzéke. Nomenclator avium Hungariae [Checklist of the birds of Hungary]. - Akadémiai Kiadó, Budapest, p. 69. (in Hungarian and German)

Kornhuber, G. A. 1856. Systematische Uebersicht der Vögel Ungerns, nebst einer kurzen Angabe ihrer unterscheidenden Charaktere [Systematical review of the birds of Hungary with short statements of their distinctive characteristics]. - Jahresprogramm der öffentl. Ober-Realschule der kön. Freistadt Presburg 6: 37-72. (in German) 
Lees, A. C. \& Gilroy, J. J. 2009. Vagrancy mechanisms in Passerines and near-Passerines. - In: Slack, R. (ed.) Rare birds, where and when. An analysis of status \& distribution in Britain and Ireland. Vol. 1. Sandgrouse to New World orioles. - Rare Bird Books, York, pp. 1-23.

Lewington, I., Alström, P. \& Colston, P. 1991. A field guide to the rare birds of Britain and Europe. - Domino Books, St. Helier, p. 348.

Lovassy, S. 1927. Magyarország gerinces állatai [Vertebrate animals of Hungary]. - Királyi Magyar Természettudományi Társulat, Budapest, pp. 300-301. (in Hungarian)

Madarász, Gy. 1881. Rendszeres névsora a magyarországi madaraknak és az ezekre vonatkozó irodalom. Systematische Auszählung der Vögel Ungarn's nebst Angabe der Literatur [Systematical checklist of the Hungarian birds and the references relevant for them]. - Buschmann Ferencz, Budapest, p. 16. (in Hungarian and German)

Madarász, Gy. 1891. Magyarázó a második Nemzetközi Ornithologiai Congressus alkalmával Budapesten rendezett magyarországi madarak kiállításához [Guide to the exhibition of the birds of Hungary organized at time of the second International Ornithological Congress in Budapest]. - Franklin Társulat, Budapest, p. 71. (in Hungarian)

Madarász, Gy. 1899-1903. Magyarország madarai. A hazai madárvilág megismerésének vezérfonala [Birds of Hungary. Guideline to the knowing of the inland birds]. - Budapest, pp. 108-109. (in Hungarian)

Magyar, G. 2006. Megjegyzések néhány vitatott fajról Magyarország madarainak névjegyzékén [Notes on some disputed species with old records on the list of the birds of Hungary]. - Aquila 113: 53-72. (in Hungarian with English Summary)

Magyar, G. 2016. Naumann és a rigója [Naumann and his thrush]. - Madártávlat 23(1): 15-16. (in Hungarian)

Magyar, G., Hadarics, T., Waliczky, Z., Schmidt, A., Nagy, T. \& Bankovics, A. 1998. Magyarország madarainak névjegyzéke. Nomenclator avium Hungariae [An annotated list of the birds of Hungary]. - KTM Természetvédelmi Hivatal Madártani Intézete - Magyar Madártani és Természetvédelmi Egyesület - Winter Fair, Budapest - Szeged, p. 106. (in Hungarian and English)

Magyar Ornitologiai Központ 1898. Nomenclator avium Regni Hungariae. Magyarország madárfajainak elnevezései [Denomination of the bird species of Hungary]. - Franklin Társulat, Budapest, p. 76. (in Hungarian)

Milchev, B. P. \& Boev, Z. N. 2014. First record of the Naumann's Thrush (Turdus naumanni Temminck, 1820, sensu lato) in Bulgaria. - Acta Zoologica Bulgarica 66(4): 559-561.

MME Nomenclator Bizottság 2008. Magyarország madarainak névjegyzéke. Nomenclator avium Hungariae [An annotated checklist of the birds of Hungary]. - Magyar Madártani és Természetvédelmi Egyesület, Budapest, p. 236. (in Hungarian and English)

MME Nomenclator Bizottság 2010. Az MME Nomenclator Bizottság 2007. évi jelentése a Magyarországon ritka madárfajok előfordulásáról [The 2007 report of the Hungarian Checklist and Rarities Committee on rare birds in Hungary]. - Aquila 116-117: 115-128. (in Hungarian with English Summary)

Naumann, J. F. 1837. Ornithologische Reise nach und durch Ungarn [Ornithological journey to and through Hungary]. - Archiv für Naturgeschichte 3(1): 69-110. (in German)

Naumann, J. F. (Hrsg.) 1845-1854. J. A. Naumann's Naturgeschichte der Vögel Deutschlands. Dreizehnter Theil. Nachträge, Zusätze und Verbesserungen [J. A. Naumann's Natural history of the birds of Germany. $13^{\text {th }}$ part. Additions, supplements and corrections]. - Hoffmann'sche Verlags-Buchhandlung, Stuttgart, pp. 296-306. (in German)

Naumann, J. F. 1851. Vorlaufige Anzeige der seit c. 30 und einigen Jahren in Deutschland vorgekommenen, früher hier nicht bemerkten oder übersehenen fremden Drossel-Arten, welche in naturgetreuen Abbildungen und Beschreibungen für die nächsten Supplement-Hefte zu meiner Naturgesch. d. Vögel Deutschlands ausführlicher dargestellt werden sollen [Preliminary notice of formerly not detected or overlooked strange thrush species occured in Germany in last cca. 30 and few years, which will be published in detail with naturalistic images and descriptions in the next supplementary issue to my Naturgesch. d. Vögel Deutschlands]. - Naumannia 1(4): 1-9. (in German)

Pfeifer, R., Stadler, J. \& Brandl, R. 2007. Birds from the Far East in Central Europe: a test of the reverse migration hypothesis. - Journal of Ornithology 148(3): 379-385.

Schenk, J. 1917. A magyar birodalom állatvilága. A Magyar Birodalomból eddig ismert állatok rendszeres lajstroma. Madarak. Fauna Regni Hungariae. Animalium Hungariae hucusque cognitorum enumeratio systematica. Aves [The fauna of the Hungarian empire. Systematic list of animals known up to now from the Hungarian Empire. Birds]. - K. M. Természettudományi Társulat, Budapest, p. 76. (in Hungarian and Latin) 
Schenk, J. 1939. A történelmi Magyarország madarainak névjegyzéke. Namenverzeichnis der Vögel des historischen Ungarns [Checklist of the birds of the historic Hungary]. - Aquila 42-45: 9-79. (in Hungarian and German)

Schmidt, E. 1988. Rőtfarkú rigó. Turdus naumanni [Naumann's Thrush. Turdus naumanni]. - In: Haraszthy, L. (ed.) Magyarország madárvendégei. - Natura, Budapest, pp. 132-133. (in Hungarian)

Schmidt, E. 1998. Naumann-rigó. Turdus naumanni [Naumann's Thrush. Turdus naumanni]. - In: Haraszthy, L. (ed.) Magyarország madarai. - Mezőgazda Kiadó, Budapest, p. 290. (in Hungarian)

Schnell, K. 1835. Naumann híres természetbúvár Pesten létele [Stay of famous naturalist Naumann in Pest]. Hasznos Mulatságok 1835(29): 230-231. (in Hungarian)

Slack, R. 2009. Rare birds, where and when. An analysis of status and distribution in Britain and Ireland. Vol. 1. Sandgrouse to New World orioles. - Rare Bird Books, York, p. 221.

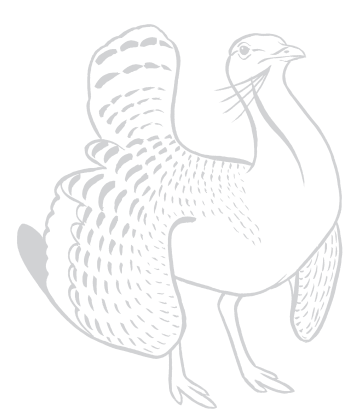

